\title{
Potential of Breast Anticancer Compounds (MCF-7) from Synthesis Results and Characterization of Complex Compounds of $\mathrm{Mg}(\mathrm{II})$ Isoleucinedithiocarbamate
}

\author{
Riswandi $^{1}$, Prihantono ${ }^{2}$, Indah Raya ${ }^{3}$, Rizal Irfandi ${ }^{4}$ \\ ${ }^{1,3,4}$ Department of Chemistry, Faculty of Mathematics, and Natural Science, Universitas \\ Hasanuddin, Indonesia. 90245 \\ ${ }^{2}$ Department of Surgery, Faculty of Medical, Universitas Hasanuddin, Indonesia. 90245 \\ \{wandykimia@gmail.com ${ }^{1}$, prihantono.md@gmail.com², indahraya05@gmail.com ${ }^{3}$, \\ rizalirfandi043@gmail.com ${ }^{4}$ \}
}

\begin{abstract}
The "in situ" method is used to synthesize the Mg (II) isoleucinedithiocarbamate complex. This complex is characterized by using Ultraviolet-Visible Spectroscopy (UV-Vis) and Infra Red (IR) Spectrum maximum. In addition, measurements of melting and conductivity are also carried out. The results obtained for UV-Vis $\mathrm{Mg}$ (II) isoleucinedithiocarbamate at $267 \mathrm{~nm}$ and $486 \mathrm{~nm}$ indicate that electronic transitions $\pi \rightarrow \pi *$ and $\mathrm{n} \rightarrow \pi^{*}$ from $\mathrm{CS}_{2}$ and $\mathrm{N}=\mathrm{C}=\mathrm{S}$. IR spectra at wavelengths in region $391-536 \mathrm{~cm}^{-1}$ shows that there has been coordination between $\mathrm{Mg}$ (II) and Sulfur (S) atoms, Nitrogen $(\mathrm{N})$ and Oxygen $(\mathrm{O})$ from the isoleucinedithiocarbamate ligand. Cytotoxic test of the $\mathrm{Mg}$ (II) isoleucinedithiocarbamate complex has $\mathrm{IC}_{50}=$ $11008.33 \mu \mathrm{g} / \mathrm{mL}$. These results indicate that MCF-7 cells undergo apoptosis seen from morphological changes.
\end{abstract}

Keywords: Complexes, Isoleucine, Dithiocarbamate, MCF-7.

\section{Introduction}

Cancer is a disease that can arise due to abnormal physical conditions and unhealthy lifestyle. In addition, cancer is a non-infectious disease [1] that can make the function of tissues and organs do not work normally due to abnormal cell division [2]. One way to stop cell division is to use chemotherapy drugs such as cisplatin. But it has high toxic properties so it has many side effects [3].

Cisplatin is able to stop cell division because it is bound by the nitrogen base contained in DNA, especially in the guanine nuclei by Pt metals that form intra-strand cross bonds. Cells become stiff because they are no longer recognized, therefore DNA cannot be repaired [4]. The nitrogen base contained in DNA is one of the most important factors in cell division. In the treatment of cancer, cisplatin and its derivatives have shown success so as to provoke many scientists to develop other metal complexes that are better in anticancer activities [5].

Based on the results of previous studies, two hundred more dithiocarbamate compounds 
have been synthesized and approximately fifty compounds have known structure. Several tests have also been conducted such as antimicrobial, anticancer, antioxidant and also to most of the dithiocarbamate complexes that have been synthesized [6]

Ditiokarbamat has a S group that can contribute monodentate and bidentate electrons [7]. A large number of ditiokarbamat compounds are known to be bound to $\mathrm{CS}_{2}$ in coordination patterns [8]. Ditiokarbamat can be complexed with metals by knowing its properties based on the HSAB principle. Mg (II) metal is hard acidic and ditiokarbamat is a soft base. Based on these properties, the metal and ditiokarbamat ligands can form complexes that have different properties than the original [9]

Nowadays no one has examined the isoleucinedithiocarbamate compound as a ligand by complexing the $\mathrm{Mg}$ metal which is expected to be able to bind to the nitrogen base in the DNA so that the cell does not divide again

\section{Material and Methods}

The materials used for this study were $\mathrm{MgSO}_{4}$, isolesuin, carbon disulfide $\left(\mathrm{CS}_{2}\right)$, Cisplatin, Roswell Park Memorial Institute Medium, DMSO, Ethanol, Acetone, n-hexane, Acetonitrile.

This research was using the insitu method. Ligands are obtained by directly reacting carbondisulfide $\left(\mathrm{CS}_{2}\right)$ and isoleucine. The ligand was then complexed with metal Magnesium $(\mathrm{Mg})$. Furthermore, the results obtained were characterized using the melting point of the Electrotermal 9100 model, conductometer, Jenwey UV-Vis spectrometer, SHIMOZU Fourier Transform Infrared spectrometer, JEOL NMR spectrometer and a set of cancer cell test kits (Biosafety Cabinet (BSC), Centrifuge, $\mathrm{CO}_{2}$ Incubator, Microscope, and Multimode Reader).

The synthesis of isoleucinedithiocarbamate ligand was conducted by weighing 0.6559 gram $(5 \mathrm{mmol})$ isoleucine which was then dissolved in $10 \mathrm{~mL}$ ethanol added by $\mathrm{CS}_{2}$ solution of 0.3 $\mathrm{mL}(5 \mathrm{mmol})$ slowly at a temperature of $10^{\circ} \mathrm{C}$

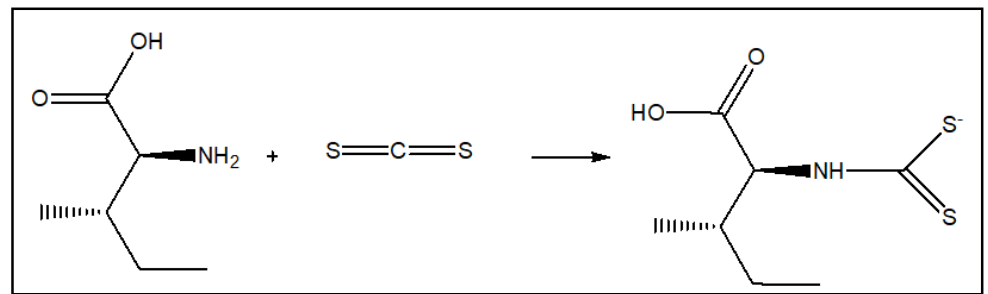

Fig. 1. Synthesis reaction of isoleusindithiocarbamate ligand

The synthesis of $\mathrm{Mg}$ (II) with isoleucinedithiocarbamate ligand was conducted by dissolving 0.7394 grams $\left(3 \mathrm{mmol}\right.$ ) of $\mathrm{MgSO}_{4}$ with $10 \mathrm{~mL}$ ethanol. The solution was added with isoleucinedithiocarbamate ligand and stirred for 30 minutes. The resulting precipitate is filtered and dried with a desiccator. After drying, crystallization was carried out with the appropriate solvent. Crystals were then analyzed and characterized.

Fig. 2. Synthesis reaction of $\mathrm{Mg}(\mathrm{II})$ isoleusindithiocarbamate

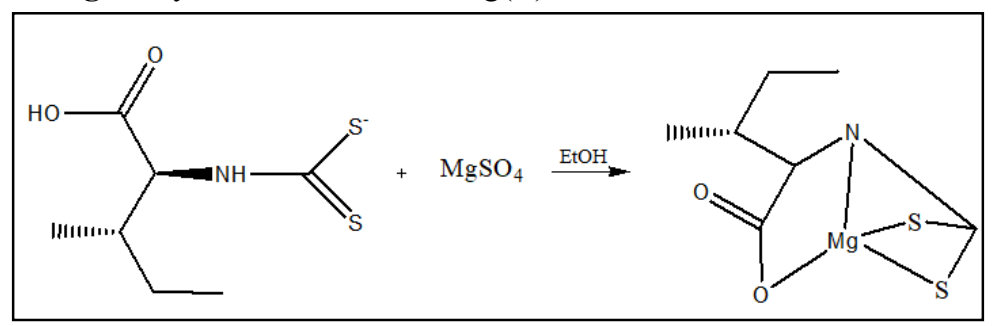


Characterization of electronic spectra results was obtained using Jenwey UV-Vis spectrophotometer 200-1100 nm, while Infrared spectra were obtained using Infrared SHIMADZU spectrophotometer, at a frequency of 4000-300 $\mathrm{cm}^{-1}$

Cytotoxic Tests on Breast Cancer Cells (MCF-7) were carried out by cell culture to be used in 96 well plates which were then incubated (at $37^{\circ} \mathrm{C}$ and $5 \% \mathrm{CO}^{2}$ gas until the percentage of cell growth reached $70 \%$ ). Cells were treated with samples and then incubated (for 24 hours at $37^{\circ} \mathrm{C}$ and $5 \% \mathrm{CO}^{2}$ gas). Add presto blue work reagents to the cell. Absorbance measurements were carried out using Multimode Reade.

\section{Results and Discussion}

The synthesis of $\mathrm{Mg}$ (II) isoleusindithiocarbamate complex compounds showed strong stability with a melting point value of $320^{\circ} \mathrm{C}-324^{\circ} \mathrm{C}$ and was a non-electrolyte compound with a conductivity value obtained at $2.02 \mathrm{mS} / \mathrm{cm}$. The result of synthesis of this compound is $47.82 \%$.

Characterization of electronic spectra results was obtained by using the Jenwey UV-Vis 200$00 \mathrm{~nm}$ spectrophotometer can be seen in table 1 below.

Table 1. UV-Vis data of Mg(II)isoleusindithiocarbamate

\begin{tabular}{ccc}
\hline Compund & $\lambda$ maksimum $(\mathrm{nm})$ & Electronic Transition \\
\cline { 2 - 3 } $\operatorname{2} \operatorname{Mg}(\mathrm{II})$ IsoleuDtc & 267 & $\pi \rightarrow \pi^{*}$ \\
\cline { 2 - 3 } & 486 & $\mathrm{n} \rightarrow \pi^{*}$ \\
\hline
\end{tabular}

IsoleuDtc $=$ Isoleucinedithiocarbamate

The results of characterization with UV-Vis in water solvents for complex compounds $\mathrm{Mg}$ (II) isoleusindithiocarbamate showed that $\mathrm{CS}_{2}$ groups resulting from intraligan transitions $\pi \rightarrow$ $\pi^{*}$ at $267 \mathrm{~nm}$ wavelength absorption occurs as shown in band I and in the absorption area of 250-300 nm R groups the nitrogen atom experiences the effects of hyperconjugation [10,11]. The shift in band II shows the intraligan transition $n \rightarrow \pi^{*}$ for group $\mathrm{N}=\mathrm{C}=\mathrm{S}$ at a wavelength of $486 \mathrm{~nm}$ for complex compounds. The graph of UV-Vis results can be seen in Figure 3.

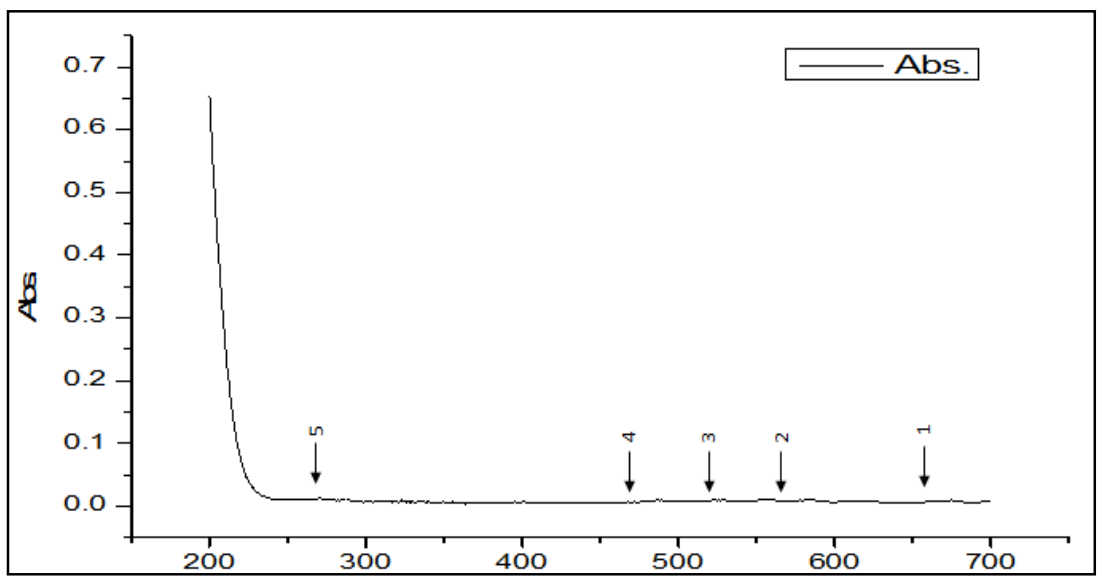

Fig.3. UV-Vis spectrum of $\mathrm{Mg}(\mathrm{II})$ isoleucinedithiocarbamate 
Characterization of Infrared spectra using SHIMADZU Infrared Spectrophotometer, in the frequency of 4000-300 $\mathrm{cm}^{-1}$ can be seen in Table 2 .

Table 2. IR absorption data of complex compounds with Isoleusinditiokarbamat ligands

\begin{tabular}{cccccc}
\hline Compund & $\mathrm{v}(\mathrm{C}=\mathrm{N})$ & $\mathrm{v}(\mathrm{C}=\mathrm{S})$ & $\mathrm{v}(\mathrm{M}-\mathrm{S})$ & $\mathrm{v}(\mathrm{M}-\mathrm{O})$ & $\mathrm{v}(\mathrm{M}-\mathrm{N})$ \\
\hline $\mathrm{Mg}(\mathrm{II})$ IsoleuDtc & $1608 \mathrm{~s}$ & $1114 \mathrm{~s}$ & $391 \mathrm{~m}$ & $486 \mathrm{w}$ & $559 \mathrm{w}$ \\
\hline & & & & \\
$\mathrm{s}=$ strong; $\mathrm{m}=$ medium; \\
$\mathrm{w}=$ weak
\end{tabular}

Identification of dithiocarbamate compounds can be seen from infrared peak absorption, namely the existence of two main types of bonds $\mathrm{C}=\mathrm{N}$ and $\mathrm{C}=\mathrm{S}$ [12]. There are two types of coordination that have absorption peaks $v(\mathrm{C}-\mathrm{S})$, namely monodentate and bidentate. The type of bidentate coordination is seen at single absorption peaks $v$ (C-S) while monodentat coordination is seen at multiple absorption peaks [13].

The dithiocarbamate complex compound that has a $\mathrm{v}(\mathrm{C}=\mathrm{N})$ bond was obtained from $\mathrm{v}$ uptake (C-N) which was located in the wave number between single bonds (1350-1250) $\mathrm{cm}^{-1}$ and double bonds (1690-1640) $\mathrm{cm}^{-1}$. Whereas CS absorption lies in wavelength number between single $C S(550-800) \mathrm{cm}^{-1}$ and double bond $\mathrm{C}=\mathrm{S}(1050-1200) \mathrm{cm}^{-1}$ so that the bond was written as $\mathrm{v}(\mathrm{C}=\mathrm{S})[11,14]$. Strain of sulfur metal bonds from ditiocarbamate ligands and metal bonds with nitrogen from bipyridyl or phenantroline ligands showed the bond between metals and ligands which observed from far infrared absorption (400-100) $\mathrm{cm}^{-1}$. [14-15]

Based on table 2., infrared absorption peaks at wave number $391 \mathrm{~cm}^{-1}$ showed the interaction of $\mathrm{S}$ atoms with metal ions $\mathrm{Mg}$. The absorption peak at wave number $486 \mathrm{~cm}^{-1}$ showed the interaction of $\mathrm{O}$ atoms of complex compounds with metal ions $\mathrm{Mg}$. The absorption peak at wave number $559 \mathrm{~cm}^{-1}$ showed the interaction of $\mathrm{N}$ atoms of complex compounds with each metal ion $\mathrm{Mg}$. The appearance of absorption at wave number $1114 \mathrm{~cm}^{-1}$ showed a single absorption peak that shows bidentate coordination between groups $(\mathrm{C}=\mathrm{S})$ with metal ions $\mathrm{Mg}$. Then there was a strong absorption at the wave number $1608 \mathrm{~cm}^{-1}$ which indicated that it was derived from the amine group $(\mathrm{C}=\mathrm{N})$. The results of the spectrum of complex compounds have been synthesized and the results are shown in figure 4.

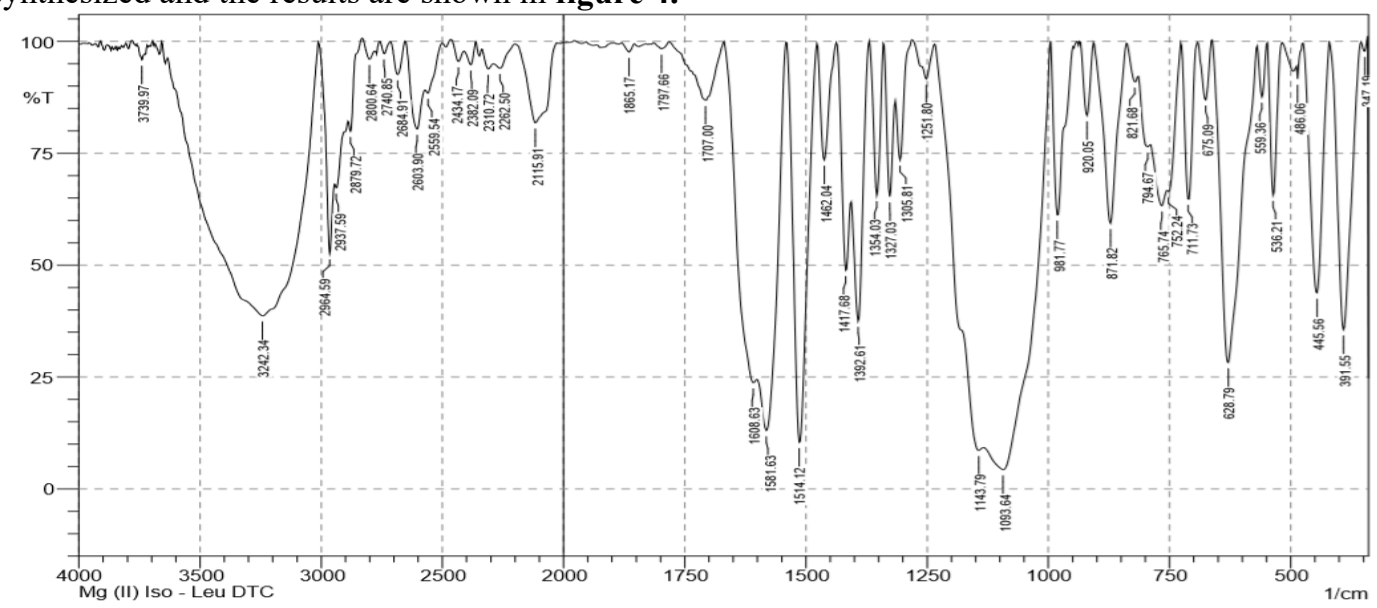

Fig.4. IR spectrum of $\mathrm{Mg}(\mathrm{II})$ isoleucinedithiocarbamate 
Cytotoxic Test on Breast Cancer Cells (MCF-7) can be seen in figure 5 below
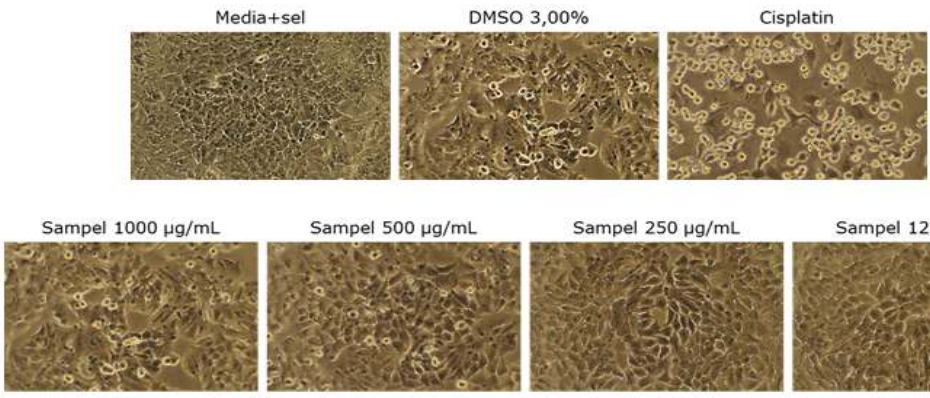

Sampel $250 \mu \mathrm{g} / \mathrm{mL}$

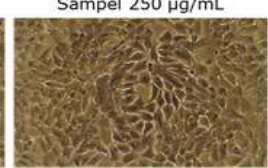

Sampel $125 \mu \mathrm{g} / \mathrm{mL}$

Sampel $62,50 \mu \mathrm{g} / \mathrm{mL}$

Sampel $31,25 \mu \mathrm{g} / \mathrm{mL}$

Sampel $15,63 \mu \mathrm{g} / \mathrm{mL}$
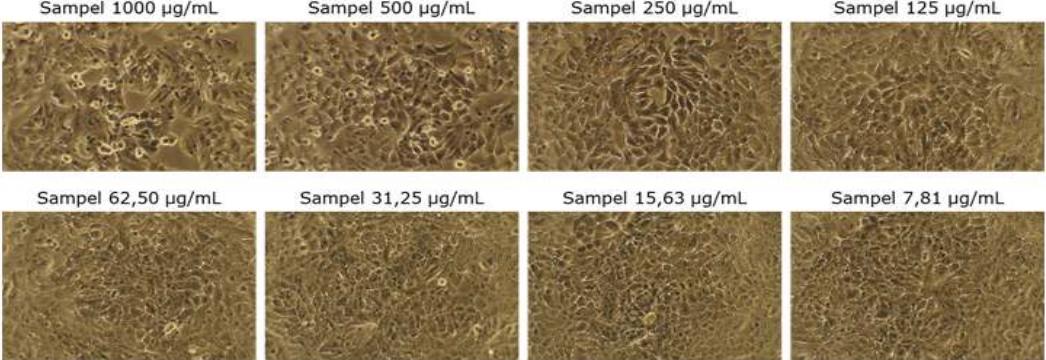

Sampel $7,81 \mu \mathrm{g} / \mathrm{mL}$

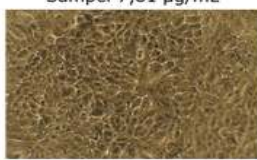

Fig.5. Morphological changes induced by $\mathrm{Mg}(\mathrm{II})$ isoleusindithiocarbamate in MCF-7 cells

Figure 5 shows that cancer cells undergo apoptosis due to the mechanism of complex compounds to cancer cells, namely complex compounds that bind adenine and guanine in double-helical DNA. The bond that occurs was covalent bonds with DNA. Metal ions can connect the two strands to form intra-strand cross-links, bind to two strands of DNA in a double helix. This intra-strand cross bond prevents cell breakdown through the mitosis process so that the tumor stops growing. Then the tumor cell becomes rigid which was induced by crosslinking on metal ions, so that it cannot be recognized and DNA cannot be repaired. The $\mathrm{IC}_{50}$ results from the anticancer cytotoxic test are $11008.33 \mu \mathrm{g} / \mathrm{mL}$ which can be used as an anticancer drug.

\section{Conclusion}

Complex characterization using UV-Vis and IR showed that the complex compound Mg (II) isoleusindithiocarbamate was successfully synthesized by the in-situ method. The complex can inhibit the activity of MCF-7 cancer cells, so that cancer cells experience apoptosis.

\section{Acknowledgements}

We thank the Inorganic Research Center Laboratory of Universitas Hasanuddin, Makassar, Indonesia for supporting this research.

\section{References}

[1] Schreiber Joseph, Paul Anderson, Humberto G. Rosas, Avery L. Buchholz, Anthony G., 2008, Hounsfield Units for Assessing Bone Mineral Density and Strength: A Tool for Osteoporosis Management, The Journal of Bone \& Joint Surgery. 93:1057- 1063 
[2] Brilliana R. Arafah, Alvita., dan Basuki Notobroto, Hari., 2017, Faktor Yang Berhubungan Dengan Perilaku Ibu Rumah Tangga Melakukan Pemeriksaan Payudara Sendiri (SADARI), The Indonesian Journal of Public Health, 12 (2): 143-153.

[3] Dorcier, Antoine., Han Ang Wee., Bolano, Sandra., Gonsalvi, Luca., Juillerat-Jeannerat, Lucienne., Laurenczy, Gabor., Peruzzini, Maurizio., D. Philips, Andrew., Zanobini, Fabrizio dan J. Dyson, Paul. In Vitro Evaluation of Rhodium and Osmium RAPTA Analogues: The Case for Organometallic Anticancer Drugs Not Based on Ruthenium. Organometallic. 2006, 25: 4090-4096.

[4] Alderden, Rebecca A., Hall, Matthew D., and Hambley, Trevor W., The Discovery and Development of Cisplatin, Journal of Chemical Education. 2006, 83(5): 728-734.

[5] Prasad, Rajendra., Mukhopadhyay, Sujay., Roop Shikha Singh., Sharma Vinay., Mobin, Shaikh M., and Shankar-Pandey, Daya., Anticancer Activity of Iridium(III) Complexes Based on a PyrazoleAppended Quinoline-Based BODIPY, Journal of ACS Inorganic Chemistry. 2017, 56: 12232-12247.

[6] Awang, N., Baba, I., dan Yamin, BM., 2006, Sintesis dan Pencirian Sebatian sekbutilpropil-ditiokarbamat daripada logam Zink (II), Cadmium(II) dan Stibium (II), Pusat Pengajian Sains Kimia dan Teknologi Makanan, Fakultas Sains dan Teknologi, Universiti Kebangsaan Malaysia, Bangi, Selangor.

[7] Rogachev, I., Gusis, V., Gusis, A., Cortina, J. L., Gressel, J., dan Warshawsky, A. Spectrofotometric Determination Of Copper Complexation Properties Of New Amphifilic Dithiocarbamates, React.Funct. Polym. 1999, 42 (3): 243-254.

[8] Bowser, J. R., Inorganic Chemistry, 1993, Brooks/Cole Publishing Compa California.

[9] Bookhari, A., Hill J. O., and Magee R. J., Nickel(II) and copper(II) complexes of monoethanol and diethanoldithiocarbamic acid. journal of nuclear Inorganic Chemistry. 1974, 36: 1253-1257.

[10] Raya, I., Baba, I., Yamin, B.M., New mixed ligan complexes of samarium(III) with dithiocarbamate and 1,10-phenantroline, Malaysia Journal of Analitycal Sciences, 2006, 10(1): 93-98.

[11] Morizzi, J., Hobday, M., and Rix, C., Gallium (III) Organophosphonate adducts with the bidentate amines 2,2'-bipyridyl and 1,10-phenantroline, Inorganica Chimica Acta. 2001, 320:67-74.

[12] Criado, J.J., Lopez, J.A, and Macias, B., Au(III) complexes of tris N-dithiocarbamate derivates of $\alpha$ - amino acids: Spectroscopic studies, thermal behavior and antibacterial activity, Inorganic Chimica Acta. 1992, 193: 229-235.

[13] Bernal, C., Neves, E.A., and Cavalheiro, T.G., Differences in thermal decomposition of $\mathrm{Ag}(\mathrm{I}), \mathrm{Mn}(\mathrm{II}), \mathrm{F}(\mathrm{II})$, and $\mathrm{Fe}(\mathrm{III})$ complexes of cyclic dithiocarbamate, Thermocemica Acta. 2001, 370(1-2): 49-55

[14] Wang, B., Ma, H-Zh., and Shi, Q-Zh., Chiral lanthanide (III) complexes of sulphurnitrogen-oxygen ligand derived from aminothiourea and sodium D-camphor- $\beta$-sulfonate, Inor Chem Commun. 2001, 4:409-412.

[15] Li, Yang., Jun, Tan., Bo-Chu, Wang., dan Lian-Cai, Zhu., 2014, Synthesis, Characterization, and Anti-Cancer Aactivity of Emodin-Mn(II) Metal Complex. Chinese Journal of Natural Medicine, 12(12): 0937-0942. 